\title{
INFLUENCE OF LINEAR HABITATS IN MAMMAL ACTIVITY: TEST OF THE TRAVEL LANES HYPOTHESIS
}

\author{
COELHO, L. H. L. \\ Instituto de Ciências Biológicas, Departamento de Biologia Geral, Universidade Federal de \\ Minas Gerais, Av. Antônio Carlos, 6627, CEP 31270-010, Belo Horizonte, MG, Brazil \\ Correspondence to: Leonardo Hoffman Leão Coelho, Instituto de Ciências Biológicas, \\ Departamento de Biologia Geral, Universidade Federal de Minas Gerais, \\ Av. Antônio Carlos, 6627, CEP 31270-010, Belo Horizonte, MG, Brazil \\ Received August 28, 1997 - Accepted September 01, 1998 - Distributed February 23, 1999
}

\begin{abstract}
Mammal activity was monitored by a track-analysis method, in a 180 ha forest fragment. Three 1 $\mathrm{km}$ transects, each one with six tracking stations were established: one along a road side and one along a stream bank ("travel lanes") and one in the forest interior. Transects were monitored for six weeks through the months of September, October and beginning of November 1996. The activity of six morphspecies of mammals was accessed, providing 251 records. Results of linear and non-linear habitats were compared, to test the "travel lanes" hypothesis, which predicts higher mammal activity in linear habitats.

No statistical evidence supporting the hypothesis was found. The roadside transect showed the lowest mammal activity, whereas the stream side transect showed the highest activity, but most of the records obtained were due to only one species; records of other species were scarce. I conclude that the "travel lane concept" should not be applied to all kind of environments, and the generality of the hypothesis should be accepted with care.
\end{abstract}

Key words: mammal activity, travel lanes, edge effects, forest fragment.

\section{RESUMO}

\section{Influência de hábitats lineares na atividade de mamíferos: teste da hipótese dos "caminhos de viagem"}

A atividade de mamíferos foi monitorada, através de um método baseado em análise de pegadas, em um fragmento de mata de 180 ha. Três transectos de $1 \mathrm{~km}$ com seis pontos de amostragem distantes $200 \mathrm{~m}$ entre si foram estabelecidos: um ao longo de uma estrada, um na margem do córrego (ambientes lineares) e um no interior da mata. Os transectos foram monitorados durante sete semanas ao longo dos meses de setembro, outubro e no início de novembro de 1996. Através da técnica utilizada, a atividade de seis morfoespécies diferentes de mamíferos puderam ser amostrados, gerando 251 registros diferentes. Os resultados obtidos em ambientes lineares e não-lineares foram comparados para testar a hipótese dos "travels lanes", que prevê maior atividade de mamíferos em ambientes lineares.

Nenhuma evidência estatística a favor da hipótese foi encontrada. O transecto da estrada mostrou a menor atividade de mamíferos e o do córrego, a maior atividade, mas a grande maioria dos registros foi atribuída a uma única espécie, tendo sido as demais muito pouco abundantes. Conclui-se que o conceito dos "travel lanes" não se aplica a todos os ambientes, e a generalidade desta hipótese deve ser considerada com precaução.

Palavras-chave: atividade de mamíferos, ambientes lineares, efeito de borda, fragmento florestal. 


\section{INTRODUCTION}

Habitat borders have important effects on abundance and diversity of some species of animals and plants, having positive and negative impacts on the communities (Leopold \& Harris apud., Heske, 1995; Medellin \& Redford, 1990) Recently, the concern about the effects of habitat fragmentation in species diversity has demanded a better understanding of habitat border effects (Shafer, 1990). Nevertheless, despite much attention having been given to bird communities, few studies have focused on mammal communities (Bider 1968; Heske 1995; Marini et al., 1995).

Bider (1968) reported higher mammal diversity along forest borders than in the interior, and stated that such borders could act as "travel lanes".

In this work, we compare mammal activity in linear and non-linear habitats to test Bider's "Travel lanes hypothesis", and to test, in a tropical forest fragment, a census technique based on the analysis of footprints, the "Dirt Track Plot" " (Barret, 1983).

\section{MATERIAL AND METHODS}

The study area comprised a forest fragment near Mutuca stream, located in the Mutuca APE $\left(20^{\circ} 03^{\prime} \mathrm{S}\right.$ and $\left.43^{\circ} 57^{\prime} \mathrm{W}\right)$, in the south of the city of Belo Horizonte, MG, near BR-040 highway. Annual rainfall is approx. $1,400 \mathrm{~mm} /$ year, most in the months of December and February.

This work was performed in a 180 ha forest fragment. Three transects of $1 \mathrm{~km}$ each were established: one in the forest border beside a road, one along a stream bank and one in the forest interior, all at least $200 \mathrm{~m}$ distant from each other. In each transect, six tracking plots were established with a distance of $200 \mathrm{~m}$. The mammal activity census was realized with footprint analysis, the "Dirt Track Plot" method" (Linhart \& Knowlton apud., Barret, 1983).

Mammal footprints were obtained by $1 \mathrm{~m}^{\prime \prime}$ cardboard plates covered with couché paper, soothed by a kerosene lamp with a kerosenecamphor mix ( 1 tablet of camphor in 11 of kerosene). In the center of each plate, a cod liver oil bait was placed. The plates were monitored daily for mammal footprints for five consecutive days each week, for four weeks between September 9 and November 16, 1996. As the rain erased the footprints, all rainy days were excluded from the analysis. For each report, plates were re-soothed and re-baited. Mammal morph-species were identified according to Becker \& Dalponte (1991), and frequency in the transect registered.

\section{RESULTS}

\section{Comparison among transects}

The roadside transect showed the least number of records (28), suggesting remarkably lower mammal activity than the others (Table 1). The forest interior transects showed 106 records, and the stream transect 117; most of these were from a single species, Didelphis albiventris.

For statistical comparison of the results, mammals were grouped in two kinds: small (rodents and mouse opossums) and medium-side (white-eared opossum, armadillo, fox and quati). The average rates of mammal activity were calculated for each transect, and Z-tests were performed using SYSTAT, comparing data obtained from the transects: forest interior $\mathrm{x}$ stream, forest interior $\mathrm{x}$ roadside and stream $\mathrm{x}$ roadside (Table 2 ). In the case of the small mammals, statistical analysis showed significant differences in the comparisons between the forest interior $\mathrm{x}$ roadside and forest interior $\mathrm{x}$ stream transects, and no significant differences between the stream $\mathrm{x}$ roadside transects. In the medium-side mammals group, significant differences were found in the comparisons between the stream $\mathrm{x}$ roadside and forest interior $\mathrm{x}$ roadside transects, with no significant difference between the stream $\mathrm{x}$ forest interior transects.

Several correlation tests were performed, comparing the activity rates of the three major mammal groups censusses (opossums, rodents and quatis). The only significant interaction found was a strong negative correlation between quati activity and rodent activity along the forest interior transect (Pearson correlation, $\mathrm{r}=-0.951, \mathrm{P}=0.001$ )

\section{Effectiveness of the "dirt track plot" method}

Six morph-species of mammals were reported through the "dirt track plot" method. It was not possible to determine the Marmosa species nor the small rodent species. Some mammals 
known to be present in the study area, such as the tayra (Eira barbara) and small felids were not recorded. Table 1 summarizes the species records.

In all, 18 plates were monitored for 22 days, in a sampling effort of 398 plates-night, from which 214 were visited (visit rate 53.5\%). In 182 visits, the plates recorded one single animal; in 32 visits two animals and on one occasion, three different animals visited the plate in one day.

\section{DISCUSSION}

One of the factors that might have influenced the number of plate records was the affinity of the animal for the bait. Crab-eating fox (Cerdocyon thous) tracks were observed along the stream more often than the only record in the plate would suggest. From the three crab-eating fox records in the experiment, in only one did the animal eat the bait, and from the eight nine-banded armadillo records, in only two did the animal eat the bait. Barret (1983) reported that coyotes (Canis latrans) were only attracted to plates with additional bait of powdered rotten egg capsules, and as it seems, canids in general have not demonstrated affinity for cod liver oil baits.

The comparison of the results obtained provided no evidence for Bider's "Travel lanes hypothesis". Statistical tests did not suggest higher mammal activity in linear habitats than in the forest interior, and except for the white-eared opossum (Didelphis albiventris) which showed higher activity along the stream transect, mammals in general showed higher activity in the forest interior (Table 2).

In the case of the nine-banded armadillo (Dasypus novemcintus) and the crab-eating fox (Cerdocyon thous), the small number of records renders suspect any statistical analysis of these results.

Heske (1995) worked in several fragments of temperate forests and did not find any significant differences between the activity of mammals in linear habitats and the forest interior; he found a high degree of variance in the results of the different sites, and stated that the generality of the concept of edge effects for mammal communities should be considered with care.

TABLE 1

Mammal records along the transects.

\begin{tabular}{|c|c|c|c|c|}
\hline \multirow[t]{2}{*}{ Morph-species of mammals } & \multicolumn{4}{|c|}{ Transects } \\
\hline & Roadside & Forest interior & Stream & Total \\
\hline White-eared opossum (Didelphis albiventris) & 7 & 40 & 93 & 140 \\
\hline Small rodents & 13 & 39 & 12 & 64 \\
\hline Quati (Nasua nasua) & 1 & 18 & 5 & 24 \\
\hline Mouse opossum (Marmosa sp.) & 0 & 8 & 0 & 8 \\
\hline Armadillo (Dasypus novemcintus) & 3 & 0 & 5 & 8 \\
\hline Crab-eating fox (Cerdocyon thous) & 1 & 1 & 1 & 3 \\
\hline Unknown & 3 & 0 & 1 & 4 \\
\hline Total & 28 & 106 & 117 & 251 \\
\hline
\end{tabular}

TABLE 2

Results from statistical comparisons of activity rates of small and medium-size mammals between the transects ( $\mathrm{z}$ test).

\begin{tabular}{l}
\hline Transects \\
Stream x roadside \\
Forest interior $\mathrm{x}$ roadside \\
Forest interior $\mathrm{x}$ stream \\
\hline
\end{tabular}

Small mammals
$Z=-0.272, P=0.785$
$Z=-2.032, P=0.042$
$Z=-2.020, P=0.043$

\begin{tabular}{l} 
Medium-size mammals \\
$Z=-2.214, P=0.027$ \\
$Z=-2.207, P=0.027$ \\
$Z=1.604, P=0.109$ \\
\hline
\end{tabular}


Marini et al., (1995) worked on the role of edge effects in nest predation and found no evidence for the hypothesis, as the distance from linear habitats did not affect the predation rate, which was not lower in the forest interior. In the present work, it has been shown that some kinds of linear habitats might have negative impacts on the activity of some mammals. Nevertheless, there is still a big lack of data about mammal communities in tropical forest fragments. More research is needed to determine edge effects in the different communities of such fragments.

Acknowledgements - I would like to thank all the people who made this work possible: Prof. Miguel Ângelo Marini for all the help; Paulo Emílio Guimarães Filho for information; COPASA for permiting access the work area; all COPASA employees in Mutuca station; and Darcy Ferreira dos Santos, from the Department of Physiology for instruction on the technique to obtain footprints

\section{REFERENCES}

BARRET, R. H., 1983, Smoked Aluminum Track Plots for Determining Furbearer Distribution and Relative Abundance. California Fish and Game, 69: 188-90.
BIDER, J. R., 1968, Animal activity in uncontrolled terrestrial communities as determined by a sand transect technique. Ecological Monographs, 38: 269-308.

BECKER, M. \& DALPONTE, J. C., 1991, Rastros de mamíferos silvestres brasileiros. Editora da Universidade de Brasília, Brasília.

HESKE, E. J., 1995, Mammalian abundance in forest-farm edges versus forest interiors in Southern Illinois: is there an Edge Effect? J. Mammal., 76(2): 562-568.

MARINI, M. A., ROBINSON, S. K. \& HESKE, E. J., 1995, Edge effects on nest predation in the Shaunee National Forest, Southern Illinois. Biol. Conserv., 74: 203-213.

MEDDELIN, R. A. \& REDFORD, K. H., 1990, The role of mammals in Neotropical forest-savanna boundairies. In: P. A. Furley, J. Proctor \& J. A. Ratter, Nature and Dynamics of Forest-Savanna Boundaries, Chapman \& Hall, , London, pp. 519-535.

SHAFER, C. L., 1990, Nature reserves: Island theory and conservation practice. Smithsonian Institution Press, Washington \& London, $185 \mathrm{p}$. 